\title{
FROM SATISFACTION IN ECO-TOURISM TO LOYALTY IN A NATIONAL PARK
}

\author{
Mauricio CARVACHE-FRANCO \\ Espíritu Santo University-Ecuador, Av. Samborondón, \\ Samborondón 092301, Ecuador, e-mail: mauricio2714@hotmail.com
}

\section{Orly CARVACHE-FRANCO}

Catholic University of Santiago de Guayaquil, Faculty of Business Specialties,

Av. Carlos Julio Arosemena Km 1.5, Guayaquil, Ecuador, e-mail: orly.carvache@cu.ucsg.edu.ec

\section{Wilmer CARVACHE-FRANCO*}

ESPOL Polytechnic University, Escuela Superior Politécnica del Litoral, ESPOL, Faculty of Social Sciences and Humanities, Campus Gustavo Galindo Km 30.5 Vía Perimetral, P.O. Box 09-01-5863, Guayaquil, Ecuador, e-mail: wcarvach@espol.edu.ec

\section{Cesar VILLAGóMEZ-BUELE}

University of Guayaquil. Faculty of Chemical Engineering, Guayaquil, Ecuador, e-mail: cesar.villagomezb@ug.edu.ec

\begin{abstract}
Citation: Carvache-Franco, M., Carvache-Franco, O., Carvache-Franco, W., \& Villagómez-Buele, C. (2020). FROM SATISFACTION IN ECO-TOURISM TO LOYALTY IN A NATIONAL PARK. GeoJournal of Tourism and Geosites, 28(1), 191-202. https://doi.org/10.30892/gtg.28115-462

Abstract: Doing ecotourism in national parks offers a wide array of opportunities to help to preserve nature while performing recreational activities. The goal of this study is to analyze the issues related to the levels of satisfaction after engaging in eco-tourism in a national park. The empirical study was conducted in-situ in Ecuador, at the Machalilla National Park, which has become an important humpback whale sighting destination. 386 questionnaires were analyzed using univariate and bivariate quantitative techniques. The findings showed an overall high level of satisfaction and loyalty to the ecotourism site. The most valued factors in the satisfaction measure were, tranquility, conservation of the natural and cultural patrimony, humane treatment received, and gastronomic quality. In eco-tourism, general satisfaction influences the intentions of returning, recommending, and saying positive things about the visited destination.
\end{abstract}

Key words: Eco-tourism, Satisfaction, loyalty, demand, Machalilla

\section{INTRODUCTION}

Ecotourists typically show significant levels of perceived satisfaction with the experiences lived during an eco-tourism visit (Buckley, 2009; Butler \& Boyd, 2000;

\footnotetext{
* Corresponding author
} 
Lawton, 2001; Weaver, 2008). For the ecotourists, finding megafaunas and impressive ecosystems are key expressive attributes of satisfaction obtained during a visit to protected areas (Blamey, 2001; Curtin, 2003; Hvenegaard, 2002). This is why managers realize the economic importance of meeting the needs of their visitors and providing them with memorable experiences (Fletcher \& Fletcher, 2003). Therefore, understanding what constitutes satisfaction allows managers to provide facilities and services that match the expectations of visitors (Borrie \& Birzell, 2001; Hornback \& Eagles, 1999; Tonge \& Moore, 2007). Likewise, visitor satisfaction is a vital aspect of the marketing and management practices carried out at national parks (Hwang et al., 2005; Ramkissoon et al., 2013).

Most studies of protected areas evaluate some necessary attributes of the site, such as boats or trails, identifying a similar trend of high levels of visitor's satisfaction (Fletcher \& Fletcher, 2003). Understanding the expectations and what brings about satisfaction to travelers, helps with planning, resource allocation and service provision (Bushell \& Griffin, 2006). It also allows adventurers to attain the natural and relaxation benefits they expect (Crilley et al., 2012). Consequently, the optimization of visitor satisfaction is often an important goal that park managers seek to achieve (Tonge \& Moore, 2007). Also, marketing approaches that consider tourism satisfaction and behavioral intentions remain as an essential area for research in tourism studies (Prayag et al., 2013). Despite the above, research in destinations related to nature has been neglected in the literature (Castellanos-Verdugo et al., 2016).

The Machalilla National Park in Ecuador is a suitable destination for the practice of eco-tourism. Among its main attractions is the sighting of humpback whales, visiting the Agua Blanca Community, doing water sports, walking through ecological trails and sighting flora and fauna. This article aims to analyze the levels of satisfaction experienced in eco-tourism, to provide information to tourism marketers that will contribute to the planning of efficient marketing strategies. This paper has been organized as follows, after the introduction, the literature is reviewed in a second heading, followed by the third section which describes the study area. After that description, the methodology of the research is looked at, to then move on to the results encompassed. The manuscript ends by presenting the discussion of the results, conclusions, limitations and the researcher's suggestions for future lines of research.

\section{REVIEW OF THE LITERATURE}

Satisfaction can be defined in three different ways. First, it can be seen as a postconsumer assessment that determines whether the service obtained meets or exceeds the consumer's expectations (Engel et al., 1993). It can also be construed as an emotional response derived from a consumer's experience (Spreng et al., 1996). In addition, it has been described as the cognitive-affective state resulting from a positive consumer experience (Bosque \& Martin, 2008). Satisfaction is a psychological aspect, which comes from visiting an environment. It is an emotional state of mind which emerges after exposure to an opportunity (Howat \& Crilley, 2007; Zabkar et al., 2010). Tourist satisfaction refers to the positive feeling or pleasure that is obtained after experiencing or consuming a tourist product (Beard \& Ragheb, 1980). The levels of satisfaction experienced by people visiting a national park or a protected area can be indirectly measured through the stimuli they receive at that area, as well as by the experiences to which they are subject when they come in contact with the natural characteristics that create the identity of the protected area (Bigne et al., 2005; Chhetri et al., 2004).

Researchers have also recognized that satisfaction depends on the products and the prices offered, as well as the quality of the services provided and the friendly 
attitude of the local inhabitants (Crompton \& Love, 1995; Li, 1997; Lounsbury \& Hoopes, 1985; Ryan, 1999; Stevens, 1992). Additionally, satisfaction is fundamental for tourism given the strong relationship between satisfaction and future customer behavior, meaning that a satisfied consumer will repeat the visit and communicate the positive aspects of such visit to others (Emir \& Kozak, 2011; Jang \& Feng, 2007; Marcussen, 2011). Satisfaction, then, is the results of a general evaluation performed by the vacationist after the purchase (Devesa et al., 2010; Sun et al., 2013; Yoon et al., 2010), which increases the likelihood that they will call on the destination again and recommend it to their friends and family members (Chi \& Qu, 2008; Prayag \& Ryan, 2012). Satisfaction is also related to the choice of destination, the consumption of products and services and the decision to return there (Chi \& Qu, 2008; Prayag \& Ryan, 2012; Žabkar et al., 2010). Therefore, satisfaction is conducive to repeated visits (Baker \& Crompton, 2000; Tonge et al., 2011), to achieving visitor loyalty (Chen \& Tsai, 2007), and is a powerful marketing tool that helps promoting the touristic site and increasing the frequency of visits (Dharmaratne et al., 2000; Sıvalığlu \& Berköz, 2012).

Several studies have shown that repeated visits to tourist destinations are related to higher levels of visitor satisfaction, due to the fact that the resulting satisfaction partly motivates those people to return and visit the same destination (Geva \& Goldman, 1991; Yuksel, 2001; Rittichainuwat et al., 2002; Tian-Cole et al., 2002). Thus, satisfaction has a positive influence on post-purchase behavior (Anderson \& Sullivan, 1990; Cronin \& Taylor, 1992; Fornell, 1992; Keaveney, 1995; Oliver, 1980; Oliver \& Swan, 1989). In addition, there is a relationship between general satisfaction and the satisfaction obtained from different issues resulting in the intention to return and recommend the visited location (Alegre \& Cladera, 2006; Baker \& Crompton, 2000; Caneen, 2003; Juaneda, 1996; Kozak, 200; Kozak \& Rimmington, 2000; Petrick, 2004; Pritchard, 2003; Ross, 1993; Um et al., 2006; Yoon \& Uysal, 2005).

In recent years, there has been a growing interest of tourists in the environment and movements directed towards the enjoyment of the natural environment (CarvacheFranco et al., 2019). In regard to studies focusing on eco-tourism satisfaction, Tsiotsou \& Vasioti (2006) who carried out an investigation on tourism services in Greece, identified a series of satisfaction factors which include "staff satisfaction", "satisfaction with food", "satisfaction with the excursion", "satisfaction with socialization "and" satisfaction with the landscape". In contrast, Meng, Tepanon, \& Uysal (2008) in their study on the satisfaction of nature-based tourism complexes in southwestern Virginia, identified other satisfaction factors, including "friendly service/quality", "outdoor activities," "accommodation" and "natural landscapes." Lee (2015) came out with the following satisfaction factors: "information services," "recreational facilities" and "safety and sustainability." Adam et al. (2019) studied the satisfaction and motivation ecotourists had in the Kakum National Park by using the following factors, "educational satisfaction," "social satisfaction," "satisfaction with sanitation," and "satisfaction with relaxation." Also, representative examples in eco-tourism include a high visitor satisfaction rate of $66 \%$ in the Pirongia Forest Park of New Zealand (Pan \& Ryan, 2007) and a 60\% satisfaction level in the Amboseli National Park of Kenya (Okello et al., 2008).

\section{STUDY AREA}

The research took place at the Machalilla National Park which is located on the coast of the province of Manabí in Ecuador. Machalilla was declared a National Park in 1979; its name comes from a significant pre-Hispanic culture of this region. This important protected territory comprises an area of 41,754 terrestrial hectares and 14,430 
marine hectares. This national park has beaches, several small islands near the coastline such as Salango, Sucre, Pedernales, and the Sombrerito, and also De La Plata Island which is an interesting venue because of its flora and fauna. The marine area of the Park was declared a Ramsar site in 1990. The Machalilla National Park's main attractions are The Frailes Beach, which has natural features with several trails ideal for eco-tourism.

De La Plata Island, located 40 kilometers away from Puerto Lopez, has five trails where visitors can observe bird species, and there are also cliffs over the island where travelers can do surface diving. The Agua Blanca Commune has an archaeological museum with pieces from the Manteño-Huancavilca culture. There is also the observation of humpback whales, from July to September, these mammals travel from the cold waters of Antarctica to bequeath to the warm waters to reproduce and have their offspring. There are several operators who with proper boats make this sighting. (Figure 1).

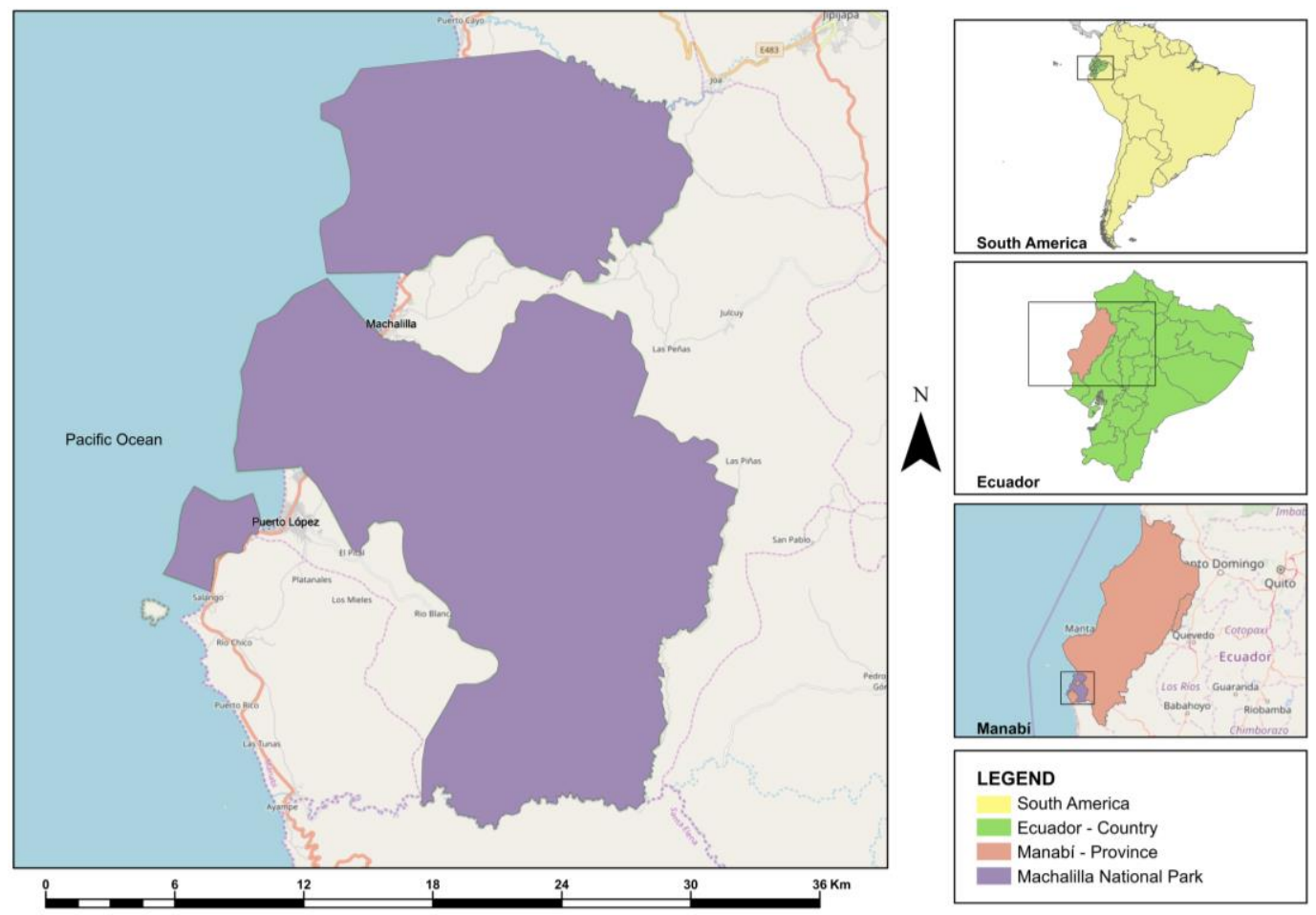

Figure 1. Geographical location of the Machalilla National Park

\section{METHODOLOGY}

A questionnaire was prepared based on several previous studies (Adam et al., 2019; Devesa et al., 2010; Lee, 2015; Meng et al., 2008; Tsiotsou \& Vasioti, 2006). The instrument was divided into two sections, in the first one sociodemographic information, such as nationality, origin, gender, age, level of training, and professional activity, was collected, while the second section dealt with satisfaction and intentions to return, recommend and say positive things about the destination. The questionnaire was designed with closed-ended questions and a five-point Likert scale to obtain reliable results. The satisfaction scale was developed with 14 items which had to be graded over a five-point Likert scale, corresponding to the different aspects of the destination. 
The Crombach Alpha coefficient for the final scale resulted in a robust value of o.86. Surveys were conducted in-situ during August and September of 2018. The surveyors received training from the authors of this article and took advantage of the moments when tourists were performing recreational activities in the national park or were resting to conduct surveys. The vacationists surveyed were people of legal age, locals or foreigners who were visiting the destination studied. The statistical data that were collected were organized, tabulated, and analyzed through the SPSS program version 22. As a statistical technique, the spearman correlation coefficient was used to know the significant relationships between the different variables. The sample size was 386 valid surveys, and the infinite population was used. With the sample achieved, he studied was conducted with a margin of error of $+/-5 \%$, a confidence level of $95 \%$ and variability of $50 \%$.

\section{RESULTS}

\section{Sociodemographic information}

Table 1. Sociodemographic aspects

\begin{tabular}{|c|c|c|c|}
\hline Demographics & Categories & $\mathbf{n}$ & $\%$ \\
\hline \multirow{2}{*}{ Nationality } & National & 292 & 75.6 \\
\hline & Foreign & 94 & 24.4 \\
\hline \multirow{5}{*}{ Origin } & North America & 8 & 2.1 \\
\hline & Europe & 42 & 10.9 \\
\hline & South America & 331 & 85.8 \\
\hline & Asia & 2 & 0.8 \\
\hline & Rest of the world & 5 & 0.5 \\
\hline \multirow{2}{*}{ Gender } & Male & 158 & 41 \\
\hline & Female & 227 & 59 \\
\hline \multirow{6}{*}{ Age } & $<20$ years old & 26 & 6.7 \\
\hline & $20-29$ years old & 162 & 42 \\
\hline & $30-39$ years old & 109 & 28.2 \\
\hline & $40-49$ years old & 50 & 13 \\
\hline & $50-59$ years old & 29 & 7.5 \\
\hline & $>59$ years old & 10 & 2.6 \\
\hline \multirow{4}{*}{ Level of education } & Primary & 6 & 1.6 \\
\hline & Secondary & 84 & 21.8 \\
\hline & University & 239 & 61.9 \\
\hline & Postgraduate/Master/Ph.D. & 57 & 14.8 \\
\hline \multirow{10}{*}{ Professional activity } & Student & 96 & 24.9 \\
\hline & Researcher / scientist & 16 & 4.1 \\
\hline & Businessman & 33 & 8.5 \\
\hline & Private Employee & 110 & 28.5 \\
\hline & Public Employee & 55 & 14.2 \\
\hline & Labores del hogar & 16 & 4.1 \\
\hline & Unemployed & 10 & 2.6 \\
\hline & Retired & 8 & 2.1 \\
\hline & Informal worker & 10 & 2.6 \\
\hline & Other & 32 & 8.3 \\
\hline \multirow{5}{*}{ Who you visit with } & Alone & 15 & 3.9 \\
\hline & With family & 216 & 56 \\
\hline & With friends & 109 & 28.2 \\
\hline & With partner & 42 & 10.9 \\
\hline & Other & 4 & 1 \\
\hline
\end{tabular}


The sociodemographic information obtained from the surveyed sample can be found in Table $1.75 .6 \%$ of the tourists were domestic, and $24.4 \%$ came from abroad. In terms of provenance, the majority group was from South America (85.8\%) followed by Europe (10.9\%). In terms of gender, $59 \%$ of the tourists were female while the remaining $41 \%$ disclosed to be male. With regards to age, the majority group was formed by those aged between 20 to 29 (42\%), followed by the group aged 30 to 39 with $28.2 \%$. $61.9 \%$ of visitors explained they had university education, followed by $21.85 \%$ of people who said they only had secondary education.

Regarding professional activity, the majority group was private employees (28.5\%), followed by the group that was students (24.9\%). The tourists surveyed mostly traveled with their families (56\%) and those visiting with friends (28.2\%).

\section{Overall satisfaction and loyalty to the destination.}

As shown in Table 2, on a Likert scale (being 1 a little and 5 a lot), the overall satisfaction of the visitor experience to the destination averaged 4.22, suggesting the high potential of the natural and cultural resources of this protected area. Also, other issues related to loyalty obtained high ratings as well.

The intentions of returning to the destination got an average of 4.32. Also, the intentions of recommending the destination returned an average of 4.49. While the variable saying positive things about the destination obtained an average of 4.56 , these findings show the important loyalty of its visitors to these protected areas.

Table 2. General satisfaction and loyalty to the destination

\begin{tabular}{|l|c|c|c|c|}
\hline Variables & N & Minimum & Maximum & Mean \\
\hline Overall satisfaction & 386 & 1 & 5 & 4.22 \\
\hline Loyalty & & & & \\
\hline I intend to return to this national park & 386 & 1 & 5 & 4.32 \\
\hline $\begin{array}{l}\text { I have the intention to recommend this protected } \\
\text { National Park }\end{array}$ & 386 & 1 & 5 & 4.49 \\
\hline $\begin{array}{l}\text { When I talk about this Natonal Park, I will give } \\
\text { positive comments }\end{array}$ & 386 & 1 & 5 & 4.56 \\
\hline
\end{tabular}

Relationship of general satisfaction with the intentions to return, recommend, and say positive things about the destination.

The relationship between general satisfaction with intentions to return, recommend, and to say positive things about destination was analyzed through a Spearman correlation. As shown in Table 3, the overall satisfaction presented a significant and positive correlation with the intentions of returning, recommending, and saying positive things about the destination. Therefore, by improving the level of general satisfaction of tourists, the intentions to return, recommend and say positive things about the destination would increase. Thus, to improve the level of general satisfaction of tourists, the relationship of general satisfaction with satisfaction in the different aspects of the service should be analyzed, as well as the aspects of the service that have a more significant influence on the overall satisfaction of the service.

Table 3. General satisfaction with the intentions to return, to recommend and say positive things

\begin{tabular}{lc}
\hline Variables & Correlation \\
\hline I have the intention to recommend this protected National Park & $.540^{* *}$ \\
When I talk about this National Park, I will give positive comments & $.533^{* *}$ \\
I intend to return to this national park & $.530^{* *}$ \\
\hline
\end{tabular}




\section{Satisfaction of the visit by aspect}

A Likert escalation was used (being 1 a little and 5 a lot) to measure the satisfaction levels in the different service-related aspects of the visit. The findings show that the most valued variables were, tranquility, which reflected an average of 4.22 , followed by natural and cultural heritage conservation (4.08), the humane treatment received (3.97) and the gastronomic quality (3.70). Results which indicate that for the visitor, it is essential that the destination conserves well its natural and cultural resources, existing excellent tranquility for the recreation and service with excellent local gastronomy (Table 4).

Table 4. Satisfaction of the visit by appearance

\begin{tabular}{|l|c|c|c|c|c|}
\hline \multicolumn{1}{|c|}{ Aspects } & $\mathrm{N}$ & Minimum & Maximum & Mean & Ranking \\
\hline Calmness & 386 & 1 & 5 & 4.22 & 1 \\
\hline Conservation of natural and cultural heritage & 386 & 1 & 5 & 4.08 & 2 \\
\hline How locals treat tourists & 386 & 1 & 5 & 3.97 & 3 \\
\hline Gastronomy & 386 & 1 & 5 & 3.76 & 4 \\
\hline Accommodation & 386 & 1 & 5 & 3.67 & 5 \\
\hline Prices & 386 & 1 & 5 & 3.6 & 6 \\
\hline Traffic signs & 386 & 1 & 5 & 3.59 & 7 \\
\hline Restaurant facilities/equipment & 386 & 1 & 5 & 3.56 & 8 \\
\hline Tourist information and signs & 386 & 1 & 5 & 3.56 & 9 \\
\hline Accessibility and infrastructure & 386 & 1 & 5 & 3.55 & 10 \\
\hline Complimentary leisure activities (festivals, shows) & 386 & 1 & 5 & 3.42 & 11 \\
\hline Parking & 386 & 1 & 5 & 3.4 & 12 \\
\hline Sport facilities & 386 & 1 & 5 & 3.3 & 13 \\
\hline Guided tours & 386 & 1 & 5 & 3.01 & 14 \\
\hline
\end{tabular}

Relationship of satisfaction by aspects with general satisfaction

The Spearman correlation coefficient was used to analyze the relationship between satisfaction by aspect with general satisfaction. Table 5 shows the said results.

Table 5. Satisfaction by aspect with general satisfaction

\begin{tabular}{|l|c|}
\hline \multicolumn{1}{|c|}{ Variable } & Coefficient \\
\hline Prices & $.450^{* *}$ \\
\hline Restaurant facilities/equipment & $.450^{* *}$ \\
\hline Accessibility and infrastructure & $.423^{* *}$ \\
\hline Traffic signs & $.423^{* *}$ \\
\hline Tourist information and signs & $.420^{* *}$ \\
\hline Calmness & $.411^{* *}$ \\
\hline Accommodation & $.408^{* *}$ \\
\hline Conservation of natural and cultural heritage & $.402^{* *}$ \\
\hline Parking & $.392^{* *}$ \\
\hline Gastronomy & $.369^{* *}$ \\
\hline How locals treat tourists & $.332^{* *}$ \\
\hline Complimentary leisure activities (festivals, shows) & $.328^{* *}$ \\
\hline Sport facilities & $.313^{* *}$ \\
\hline Guided tours & $.184^{* *}$ \\
\hline
\end{tabular}

${ }^{* * *}$ Significance at $1 \%$

According to Table 5, all the satisfaction aspect variables presented a significant and positive correlation with the overall satisfaction. The variables that had a greater influence 
on the overall satisfaction level are prices, equipment, and facilities of restaurants, accessibility and infrastructure and road signs. These were the service variables that should be improved in order to increase the level of overall satisfaction in this destination.

\section{the destination}

Relationship of satisfaction by aspect with the intentions of return in to

To analyze the relationship of satisfaction by aspect with the intentions of returning to the destination, the Spearman correlation coefficient was used.

The results are shown in Table 6. According to Table 6, all the satisfaction aspect variables, except for the guided visits, presented a significant and positive correlation with the intentions of returning to the destination. Thus, the variables that had a more considerable influence on the intentions of returning to the destination were tranquility, road signs, accommodation and the conservation of natural and cultural heritage. These are the service variables that can be improved in order to increase the level of intentions to return to this destination.

Table 6. Satisfaction by aspect with intentions to return to the destination

\begin{tabular}{|l|c|}
\hline \multicolumn{1}{|c|}{ Variable } & Coefficient \\
\hline Calmness & $.379^{* *}$ \\
\hline Traffic signs & $.344^{* *}$ \\
\hline Accommodation & $.344^{* *}$ \\
\hline Conservation of natural and cultural heritage & $.342^{* *}$ \\
\hline Accesibilidad e infraestructura & $.301^{* *}$ \\
\hline Gastronomy & $.308^{* *}$ \\
\hline Tourist information and signs & $.273^{* *}$ \\
\hline Restaurant facilities/equipment & $.271^{* *}$ \\
\hline Parking & $.243^{* *}$ \\
\hline Prices & $.226^{* *}$ \\
\hline Complimentary leisure activities (festivals, shows) & $.217^{* *}$ \\
\hline How locals treat tourists & $.198^{* *}$ \\
\hline Sport facilities & $.189^{* *}$ \\
\hline Guided tours & .053 \\
\hline$* *$ Significance at $1 \%$ & \\
\hline
\end{tabular}

** Significance at $1 \%$

\section{Relationship of satisfaction with aspects with the intentions torecommend the destination}

To analyze the relationship of satisfaction by aspect with the intentions of recommending the destination, the Spearman correlation coefficient was used. The results are shown in Table 7 . According to Table 7 , all the satisfaction aspect variables present a significant and positive correlation with the intentions of recommending the visited destination. The variables that had a greater influence on the intentions to recommend the destination were, road signs, tranquility, accessibility and infrastructure, and conservation of the natural and cultural heritage.

The findings show that these were the service variables that should be improved in order to increase the level of intentions to recommend the destination.

\section{DISCUSSION AND CONCLUSIONS}

The opportunities offered by a national park to do eco-tourism are varied concerning knowing the nature and culture of the destination. There are activities such as whale observation, hiking trails, visiting communities and doing water sports, and then enjoying the exquisite local gastronomy. In a destination with a high eco-tourism 
potential, it is necessary to measure the aspects of the service that influence the general satisfaction of the visitors. In addition to measuring the relationship between the general satisfaction levels with other variables related to loyalty to plan efficient strategies that can improve the level of satisfaction of visitors, increase their return to the destination, improve the image of the destination and bring benefits to the community.

Table 7. Satisfaction by appearance with intentions to recommend the destination

\begin{tabular}{|l|c|}
\hline \multicolumn{1}{|c|}{ Variable } & Correlation \\
\hline Traffic signs & $.369^{* *}$ \\
\hline Calmness & $.360^{* *}$ \\
\hline Accessibility and infrastructure & $.343^{* *}$ \\
\hline Conservation of natural and cultural heritage & $.343^{* *}$ \\
\hline Accommodation & $.335^{* *}$ \\
\hline Gastronomy & $.298^{* *}$ \\
\hline Tourist information and signs & $.282^{* *}$ \\
\hline Restaurant facilities/equipment & $.272^{* *}$ \\
\hline How locals treat tourists & $.256^{* *}$ \\
\hline Parking & $.250^{* *}$ \\
\hline Prices & $.244^{* *}$ \\
\hline Sport facilities & $.208^{* *}$ \\
\hline Complimentary leisure activities (festivals, shows) & $.207^{* *}$ \\
\hline Guided tours & $.101^{*}$ \\
\hline
\end{tabular}

The findings show that overall satisfaction was high, along with the intentions of returning to the destination. The most valued factors in the satisfaction reading were, the tranquility, the conservation of the natural and cultural patrimony, humane treatment received, and gastronomic quality. In eco-tourism, general satisfaction influences the intentions of returning to the destination; similar results have been reported (Baker \& Crompton, 2000, Chi \& Qu, 2008, Prayag \& Ryan, 2012, Tonge et al., 2011; Žabkar et al., 2010). Besides, it influences the intentions of recommending the destination, findings which are similar to those accounted for in other studies (Chi \& Qu, 2008; Prayag \& Ryan, 2012). It also influences the intentions of saying positive things about the destination, analogous to previously identified results (Emir \& Kozak, 2011; Jang \& Feng, 2007; Marcussen, 2011). Thus, all the variables of satisfaction by aspect influence general satisfaction. Also, all the variables of satisfaction by appearance, except for the variable "guided tour," influence the intentions of returning to the destination. Also, all the variables of satisfaction by aspect influence the intentions of recommending the destination. Similar results were observed in earlier pieces of research (Alegre \& Cladera, 2006; Baker \& Crompton, 2000; Caneen, 2003; Juaneda, 1996; Kozak, 200; Kozak \& Rimmington, 2000; Petrick, 2004; Pritchard, 2003; Ross, 1993; Um et al., 2006; Yoon \& Uysal, 2005).

In eco-tourism, general satisfaction is mostly influenced by prices, equipment, and facilities of restaurants, accessibility and infrastructure and road signs. While the intentions of returning to the destination are more influenced by the tranquility, the road signs, accommodation and conservation of natural and cultural heritage.

Instead, the intentions of recommending the destination are more influenced by road signs, tranquility, accessibility and infrastructure and the conservation of natural and cultural heritage. Therefore, it is necessary to improve work on these variables to 
increase the level of general satisfaction on the part of the tourists, and in this way increase the intentions of returning and recommending this destination. Among the practical implications we have that companies related to eco-tourism should plan strategies to improve the level of satisfaction in the different aspects of the service taking into account these empirical results. In this way they should be able to improve the level of general satisfaction of tourists, increase future visits and improve the recommendation of the destination, contributing to the sustainable development of the destination and the community. Finally, the main limitation of the present study was the temporality of the information gathering because the demand may vary. As a future line of research, it would be interesting to carry out a study on the relationship that exists between satisfaction and the sustainable economic impact in a national park.

\section{REFERENCES}

Adam, I., Adongo, C. A. \& Amuquandoh, F. E. (2019). A structural decompositional analysis of eco-visitors' motivations, satisfaction and post-purchase behaviour. Journal of Eco-tourism, 18(1), 60-81.

Alegre, J. \& Cladera, M. (2006). Repeat visitation in mature sun and sand holiday destinations. Journal of Travel Research, Vol. 44 No. 3, pp. 88-97.

Anderson, E.W. \& Sullivan, M.W. (1990). Customer satisfaction and retention across firms. in Zeithaml, V.A., Berry, L.L. and Parasuraman, A. (Eds), TIMS College of Marketing Special Interest Conference on Service Marketing, Nashville, TN, September.

Baker, D. A. \& Crompton, J. L. (2000). Quality, satisfaction and behavioral intentions. Annals of Tourism Research, 27(3), 785-804.

Baker, D.A. \& Crompton, J.L. (2000). Quality, satisfaction and behavioral intentions. Annals of Tourism Research, Vol. 27 No. 3, pp. 785-804

Beard, J. G. \& Ragheb, M. G. (1980). Measuring leisure satisfaction. Journal of leisure Research, $12(1), 20-33$.

Bigne, J.E., Andreu, L. \& Gnoth, J. (2005). The Theme Park experience: an analysis, of pleasure, arousal and satisfaction. Tourism Management, 26 (6), 833-844.

Blamey, R. (2001). Principles of eco-tourism. In D. Weaver (Ed.), The encyclopedia of eco-tourism (pp. 5-22). Wallingford: CABI.

Borrie, W.T. \& Birzell, R.M. (2001). Approaches to measuring quality of the wilderness experience. Missoula, MT, US Department of Agriculture, Forest Service, Rocky Mountain Research Station.

Bosque, I.R.D. \& Martin, H.S. (2008). Tourism satisfaction: A cognitive-affective model. Annals of Tourism Research, 35, 551-573.

Buckley, R. (2009). Eco-tourism: Principles and practices. Wallingford: CABI.

Bushell, R. \& Griffin, T. (2006). Monitoring visitor experiences in protected areas. Parks: The International Journal for Protected Areas Managers, 16(2), 25-33.

Butler, R. \& Boyd, S. (2000). Tourism and national parks: Issues and implications. Chichester: Wiley (Eds.).

Caneen, J.M. (2003), Cultural determinants of tourism intention to return, Tourism Analysis, Vol. 8, pp. $237-42$.

Carvache-Franco, M., Segarra-Oña, M. \& Carrascosa-López, C. (2019). Motivations Analysis In Ecotourism Through An Empirical Application: Segmentation, Characteristics And Motivations Of The Consumer. GeoJournal of Tourism and Geosites, 24 (1), 60-73. https://doi.org/10.30892/gtg.24106-343

Castellanos-Verdugo, M., Vega-Vázquez, M., Oviedo-García, M. Á. \& Orgaz-Agüera, F. (2016). The relevance of psychological factors in the ecotourist experience satisfaction through ecotourist site perceived value. Journal of Cleaner Production, 124, 226-235.

Chen, C. \& Tsai, D. (2007). How destination image and evaluative factors affect behavioral intentions? Tourism Management, 28(4), 1115-1122.

Chhetri, P., Arrowsmith, C. \& Jackson, M. (2004). Determining hiking experiences in nature-based tourist destinations. Tourism Management, 25 (1), 31-43.

Chi, C.G. \& Qu, H. (2008). Examining structural relationship of destination image, tourist satisfaction and destination loyalty: an integrated approach. Tourism Manage, 29(4), 624-636. http://dx.doi.org/ 10.1016/j.tourman.2007.06.007. 
Crilley, G., Weber, D. \& Taplin, R. (2012). Predicting visitor satisfaction in parks: Comparing the value of personal benefit attainment and service levels in Kakadu National Park, Australia. Visitor Studies, 15(2), 217-237.

Crompton, J.L. \& Love, L.L. (1995). The predictive value of alternative approaches to evaluating quality of a festival. Journal of Travel Research, 34 (1), 11-24

Cronin, J.J. \& Taylor, S.A. (1992). Measuring service quality: a re-examination and extension. Journal of Marketing, Vol. 56 No. 3, pp. 55-68.

Curtin, S. (2003). Whale-watching in Kaikoura: Sustainable destination development? Journal of Eco-tourism, 2(3), 173- 195 .

Devesa, M., Laguna, M. \& Palacios, A. (2010). The role of motivation in visitor satisfaction: Empirical evidence in rural tourism. Tourism Manage, 31(4), 547-552. http://dx.doi.org/10.1016/j.tourman.2009.06.oo6.

Dharmaratne, G. S., Yee Sang, F. \& Walling, L. J. (2000). Tourism potentials for financing protected areas. Annals of Tourism Research, 27(3), 590-610.

Engel, J., Blackwell, R. \& Miniard, P. (1993). Consumer behavior. Orlando, FL: Dryden Press.

Fletcher, D. \& Fletcher, H. (2003). Manageable predictors of park visitor satisfaction: Maintenance and personnel. Journal of Park and Recreation Administration, 21, 21 -37.

Fornell, C. (1992), A national customer satisfaction barometer: the Swedish experience. Journal of Marketing, Vol. 56 No. 1, pp. 6-21.

Geva, A. \& Goldman, A., (1991). Satisfaction measurement in guided tours. Annals of Tourism Research, 18, 177-185.

Hornback, K.E. \& Eagles, P.F.J. (1999). Guidelines for public use measurement and reporting at parks and protected areas. Gland, Switzerland and Cambridge, UK, IUCN.

Howat, G. \& Crilley, G. (2007). Customer service quality, satisfaction and operational performance: A proposed model for Australian public aquatic centres. Annals of Leisure Research, 10, no. 2: 16895.

Hvenegaard, G.T. (2002). Using tourist typologies for eco-tourism research. Journal of Eco-tourism, 7(2\&3), 137-146.

Hwang, S. N., Lee, C. \& Chen, H. J. (2005). The relationship among tourists' involvement, place attachment and interpretation satisfaction in Taiwan's national parks. Tourism Management. 26(2), 143-156.

Juaneda, C. (1996). Estimating the probability of return visits using a survey of tourist expenditure in the Balearic Islands. Tourism Economics, Vol. 2 No. 4, pp. 339-52.

Keaveney, S.M. (1995), Customer switching behavior in service industries: an exploratory study, Journal of Marketing, Vol. 59 No. 2, pp. 71-82.

Kozak, M. (2001), Repeaters' behavior at two distinct destinations, Annals of Tourism Research, Vol. 28 No. 3 , pp. 784-807.

Kozak, M. \& Rimmington, M. (2000), Tourist satisfaction with Mallorca, Spain, as an off-season holiday destination, Journal of Travel Research, Vol. 38 No. 3, pp. 260-9.

Lawton, L. (2001). Public protected areas. In D.B. Weaver (Ed.), The encyclopedia of eco-tourism (pp. 287 302). Wallingford: $\mathrm{CAB}$ International.

Lee, C. F. (2015). Tourist satisfaction with forest recreation experience: a segment-based approach. Anatolia, 26(4), 535-548.

Lounsbury, J.W. \& Hoopes, L.L. (1985). An investigation of factors associated with vacation satisfaction. Journal of Leisure Research, 17 (1), 1-13.

Meng, F., Tepanon, Y. \& Uysal, M. (2008). Measuring tourist satisfaction by attribute and motivation: The case of a nature-based resort. Journal of vacation marketing, 14(1), 41-56.

Okello, M., D’Amour, D. \& Manka, S. (2008). Tourism attractions and satisfaction of Amboseli National Park, Kenya. Tourism Analysis, 13(4), 373- 386.

Oliver, R.L. (1980), A cognitive model of the antecedents and consequences of satisfaction decisions. Journal of Marketing Research, Vol. 17 No. 4, pp. 46-9.

Oliver, R.L. \& Swan, J.E. (1989), Consumer perceptions of interpersonal equity and satisfaction in transactions: a field survey approach. Journal of Marketing, Vol. 53 No. 2, pp. 21-35.

Pan, S., \& Ryan, C. (2007). Mountain areas and visitor usage - motivations and determinants of satisfaction: The case of Pirongia Forest Park, New Zealand. Journal of Sustainable Tourism, 15(3), 288- 308.

Petrick, J.F. (2004a). Are loyal visitors desired visitors? Tourism Management, Vol. 25 No. 4, pp. 463-70.

Prayag, G., Hosany, S. \& Odeh, K. (2013). The role of tourists' emotional experiences and satisfaction in understanding behavioral intentions. J. of Destination Mark. and Manag. 2(2), 118-127. http://dx.doi.org/10.1016/j.jdmm.2013.05.001.

Prayag, G. \& Ryan, R. (2012). Antecedents of tourists' loyalty to Mauritius: The role and influence of destination image, place attachment, personal involvement, and satisfaction. J. Travel Res. 51(3), 342-356. 
Pritchard, M.P. (2003), The attitudinal and behavioral consequences of destination performance. Tourism Analysis, Vol. 8 No. 1, pp. 61-73.

Qu, H.L. \& Li, I. (1997). The characteristics and satisfaction of mainland Chinese visitors to Hong Kong. Journal of Travel Research, 35 (4), 37-41.

Ramkissoon, H., Smith, L. D. G. \& Weiler, B. (2013). Testing the dimensionality of place attachment and its relationships with place satisfaction and pro-environmental behaviours: A structural equation modelling approach. Tourism Management, 36, 552-566.

Rittichainuwat, B.N., Qu, H.L. \& Mongknonvanit, C. (2002). A study of the impact of travel satisfaction on the likelihood of travellers to revisit Thailand. Journal of Travel and Tourism Marketing, 12 (2/3), 19-43.

Ross, G.F. (1993) Destination evaluation and vacation preferences, Annals of Tourism Research, Vol. 20 No. 3, pp. 477-89.

Ryan, C. (1999). From the psychometrics of SERVQUAL to sex: measurements of tourism satisfaction. In: Pizam, A., Mansfeld, Y. (Eds.), Consumer Behavior in Travel and Tourism. The Haworth Hospitality Press, New York, pp. 267-286.

Sivalığlu, P. \& Berköz, L. (2012). Perceptual evaluation of the national park users. Procedia - Social and Behavioral Sciences, 50(o), 928-940.

Spreng, R., Mackenzie, S. \& Olshavsky, R. (1996). A re-examination of the determinants of consumer satisfaction. Journal of Marketing, 6o(3), 15-32.

Stevens, B.F. (1992). Price value perceptions of travellers. Journal of Travel Research, 31 (2), 44-48.

Sun, X., Chi, C.G. \& Xu, H. (2013). Developing destination loyalty: the case of Hainan Island. Ann. Tourism Res. 43(October), 547-577. http://dx.doi.org/10.1016/j.annals.2013.04.006.

Tian-Cole, S., Crompton, J. \& Willson, V. (2002). An empirical investigation of the relationships between service quality, satisfaction and behavioral intentions among visitors to a wildlife refuge. Journal of Leisure Research, 34 (1), 1-24

Tonge, J. \& Moore, S. A. (2007). Importance-satisfaction analysis for marine-park hinterlands: A Western Australian case study. Tourism Management, 28(3), 768-776.

Tonge, J. \& S.A. Moore. 2007. Importance-satisfaction analysis for marine-park hinterlands: A Western Australian case study. Tourism Management, 28, no. 3: 76876.

Tonge, J., Moore, S. A. \& Taplin, R. (2011). Visitor satisfaction analysis as a tool for park managers: A review and case study. Annals of Leisure Research, 14(4), 289-303.

Tsiotsou, R. \& Vasioti, E. (2006). Using demographics and leisure activities to predict satisfaction with tourism services in Greece. Journal of Hospitality \& Leisure Marketing, 14(2), 69-82.

Um, S., Chon, K. \& Ro, Y. (2006). Antecedents of revisit intention, Annals of Tourism Research, Vol. 33 No. 4, pp. 1141-58.

Weaver, D. (2008). Eco-tourism (2nd ed.). Milton: Wiley

Yoon, Y. \& Uysal, M. (2005). An examination of the effects of motivation and satisfaction on destination loyalty: a structural model. Tourism Management, Vol. 26 No. 1, pp. 45-56.

Yoon, Y., Lee, J. \& Lee, C. (2010). Measuring festival quality and value affecting visitors' satisfaction and loyalty using structural approach. Int. J. Hosp. Manag. 29(2), 335-342. http://dx.doi.org/10.1016/ j.ijhm.2009.10.002.

Yuksel, A. (2001). Managing customer satisfaction and retention: a case of tourist destinations, Turkey. Journal of Vacation Marketing 7 (2), 153-168.

Zabkar, V., Brencic, M.M. \& Dmitrovic, T. (2010). Modelling perceived quality, visitor satisfaction and behavioural intentions at the destination level. Tourism Management, 31, no. 4: 53746.

Žabkar,V., Brenčič, M.M. \& Dmitrović, T. (2010). Modelling perceived quality, visitor satisfaction and behavioural intentions at the destination level. Tourism Manage, 31(4), 537-546. http://dx.doi.org/10.1016/j.t

Submitted:

05.10.2019
Revised:

15.02 .2020
Accepted and published online 21.02.2020 